\title{
Argumentum ad Hominem in Presidential Candidate's Debate in Indonesia: Forms and Functions
}

\author{
Mohamad Jazeri ${ }^{1}$, Sukarsono ${ }^{2}$, Endang Sumarti ${ }^{3}$ \\ \{m-jazeri2018@iain-tulungagung.ac.id ${ }^{1}$, sukarsono71@ gmail.com², \\ endangsumarti@yahoo.com $\left.{ }^{3}\right\}$ \\ 1,2 IAIN Tulungagung, East Java, Indonesia \\ ${ }^{3}$ IKIP Budi Utomo, Malang, Indonesia
}

\begin{abstract}
In formal logic, ad hominem argument is fallacius, but in political debate, such argument frequently occurs. This study aims to describe the forms, message, and motivation in using argumentum ad hominem in the dabate of presidential candidates in Indonesia. This study is qualitatively approached by using pragmatics framework. The data were collected through documentation technique, derived from the broadcasted debates of presidential candidates on TV in 2019. The collected data were analyzed by the interactive model of Miles dan Huberman. Considering the fact that the arguments in political debate contains a variety of interests, the researchers applied message analysis coined by Vedung, comprising two steps, namely content analysis and function analysis. Based on data analysis, the study discovers some findings as follow; first, argumentum ad hominem practiced in the debate can be categorized into three functions, i.e.: (1) attacking the debate opponent, (2) attacking the party of debate opponent, and (3) attacking the supporters of the debate opponent. The political motivations of using argumentum ad hominem in the debate are: (1) judging or criticizing the debate opponent's ideas, (2) cornering the debate opponent.
\end{abstract}

Keywords: argumentum ad hominem, fallacy, motivation, politics, debate.

\section{INTRODUCTION}

The practices of democracy in Indonesia have gained significant progress since 2009 due to the programming of presidential candidates' debate in the general election in the country. Such an event has never been held in the previous regime, which tended to hinder the people's freedom of speech, especially those who oppose against the government's policy. The debate events have been broadcasted on several national TVs so that millions of Indonesian people can view them. Like the audience attending in the TV's studio, the viewers at homes also polarized their supports to either paired candidates number 01 (Joko Widodo-Ma'ruf Amin) or number 02 (Prabowo Subianto-Sandiaga Uno).

The debate of presidential candidates on TV, similar to other kinds of political debate, can be analyzed in two respects, i.e.: (i) the interest of formal logic, by which the argument needs to be constructed in accordance with the logical rules and common sense and (ii) the interest 
of practical politics aiming at winning the people's votes. The former refers to the interests of the political message and the latter is related to the interests of political motivation, i.e the intention and political calculations [1]. As such, Hess-Luttich (2007) account that political debate is a double games, both presenting rational arguments and avoiding it at the same time [2].

Political debate is sometimes called as "battle talk". As a battle, it often uses inappropriate language and interpretation, invalid arguments and verbal violence, even conversational violance [3]. In addition, in political debate the debaters generally mean to harrass their opponents by attacking the personality via argumentum ad hominem [4];[5]. The similar previous studies also found several uses of argumentative fallacies such as ad populum and ad hominem argument in the debates broacasted on TV [6]; . Furhermore, those fallacies are purposively utilized as a debating strategy in politics. [7];[8]. In fact, political debate reveals not only the existing relation between language and logic but also the relation between language and power. In other words, in a political debate, the debaters want to convey both political message and motivation as well as political calculation.

Presidential candidates' debate in Indonesia is conducted under the rules constructed by the General Election Commission of Indonesia, by which the debaters are not allowed to attack the personal issues of the opponent. However, there are indeed several uses of argumentum ad hominem in it. Hence, it raises such questions as; How is argumentum ad hominem practiced in the debates of Indonesian presidential candidates in 2019? Also, what political motivation underlies the uses of argumentum ad hominem in those debates? Those questions are the focuses of the present study.

\section{METHOD}

This study is qualitatively approached by using pragmatics framework. The data are in the forms of statements containing ad hominem argument made by the debaters in presidential candidates' debates between contestant couple (01) Joko Widodo-Ma'ruf Amin and (02) Prabowo Subianto-Sandiaga Uno. The debate sessions were lively broadcasted by several TVs. In addition to being broadcasted on national TVs, the debates were also uploaded in YouTube. Therefore, the recorded data of debates were practically downloaded from it. In turn, the debate was trancribed in order to analyze the uses of argumentum ad hominem. The research data were analyzed with qualitative data analysis adopted from Miles and Huberman, covering such steps as data collection, data reduction, data presentation, as well as verification and final drawing of conclusions [9]. To understand the meaning beyond the text, the researchers used political message-analysis by Vedung (1982) [1]. This analysis consists of two steps, namely content analysis and function analysis. Content analysis concerns with the contents of the message while the function analysis is associated with the motivation and the political calculations led to the production of the arguments.

\section{RESULT AND DISCUSSION}

Based on the data analysis, the researcher found that the forms of argumentum ad hominem in the debates are of three types. They are (1) attacking the debate opponent's privacy, (2) attacking the debate opponent's party, and (3) attacking the supporters of the debate opponent. Meanwhile, the functions of argument in a debate are judging or critcizing the ideas and cornering the debate opponent. Those findings will be explicated as follow: 


\subsection{The Realizations of Argumentum ad Hominem in the Presidential Candidate's debates}

3.1.1 Attacking the personal aspect of the opponent

Jokowi : Rakyat Indonesia yang saya cintai, ee pembagian yang tadi sudah saya sampaikan hampir 2,6 juta itu adalah memang agar produktif, dan sekali lagi kita tidak memberikan kepada yang gede-gede. Saya tahu Pak Prabowo memiliki lahan yang sangat luas di Kalimantan Timur se sebesar 220 ribu hektar, juga di Aceh Tengah 120 ribu hektar. Saya hanya ingin menyampaikan bahwa, bahwa pembagianpembagian seperti ini tidak dilakukan masa pemerintahan saya. 'My beloved Indonesian people, er... the redistribution I just mentioned is about 2,6 millions hectares, which are meant to be productive, and once more we don't give it to the rich and the big company. I know that Mr. Prabowo has owned very vast land in Kalimantan, as vast as $\mathbf{2 2 0 . 0 0 0}$ hectares, and $\mathbf{1 2 0 . 0 0 0}$ hectares in central Aceh as well. I want to convey that such distributions are not granted during my administration. (A.1.1).

The data above is a form of argumentum ad hominem occuring in the debate of presidential candidates in 2019. This argument was given as the response of Prabowo's criticism on the government's policy of granting the land certificates for free, conducted by Jokowi. Such a policy is accounted as ineffective and made Jokowi rebut Prabowo, as given in datum (A.1.1). It was an attack to Prabowo's privacy, who possessed that great deal of land while the common folk hardly possess a little land for farming in order to earn for living. In fact, he is the contestant who owns thousands of hectares of land in Kalimantan and Aceh despite his criticism of Jokowi's land reform policy.

\subsubsection{Attacking the opponent's political party}

Jokowi : Kita tahu (korupsi) adalah kejahatan yang luar biasa. Bahkan Pak Prabowo pernah mengatakan bahwa korupsi di Indonesia sudah stadium 4, meskipun ini saya nggak setuju saya nggak setuju. Tapi menurut ICW(Indonesian Corruption Watch), ini menurut ICW, partai yang Bapak pimpin termasuk yang paling banyak mencalonkan mantan koruptor atau mantan napi korupsi yang saya tahu caleg itu yang tanda tangan ada ketua umumnya berarti Pak Prabowo yang tanda tangan. Bagaimana Bapak menjelaskan mengenai ini? 'We know that (corruption) is an extraordinary crime. Even Mr. Prabowo has stated that the corruption crime in Indonesia has been of the fourth stadium, in spite of my disagreement. But according to ICW, your party has legalized ex-corruptors to be the legislator candidates. As I know they are under your authority as the top leader of a party. How do you explain it then? (B.1.1)

The data datum above is an example of argument that attacks the political party of the debate opponent. Here, Jokowi attacked Prabowo by mentioning that Prabowo is inconsistent with his vision and mission in term of eradicating corruption. However, the party under his authority is the one endorsing most ex-corruptors to become the prospective lagislators in general election of 2019 .

\subsubsection{Attacking the Opponent's Supporters}

Prabowo: Kami ingin bertanya bahwa Bapak kan sudah ee memerintah selama 4 tahun lebih yang kita ketemuken adalah perasaan di masyarakat bahwa kadang-kadang aparat itu berat sebelah, sebagai contoh kalau ada kepala daerah gubernur-gubernur 
yang mendukung paslon nomer satu, itu menyatakan dukungan tidak apa-apa, tapi ada kepala desa di Jawa Timur menyatakan dukungan kepada kami sekarang ditahan Pak ditangkap. We would like to ask... In fact, you have held the administration for more than 4 years. What we have found isthat there is a feeling in the community that sometimes the government officers seem unfair; take for example if there are some governors supporting the contestants number one, that's fine, no problem... But there is a village chief claiming to support us is now in detention Sir... being arrested. (C.1.1)

Jokowi: ... Jangan, kita ini sering suka, grusa-grusu menyampaikan sesuatu misalnya, apa jurkamnya Pak Prabowo, misalnya ini, katanya dianiaya mukanya babak belur kemudian konferensi pers bersama-sama akhirnya apa yang terjadi? Ternyata operasi plastik. Ini negara hukum. Kalau ada bukti, silakan lewat mekanisme hukum. Laporkan dengan bukti-bukti yang ada. Gampang sekali kok, gampang sekali, negara hukum ini. Kenapa harus menuduh-nuduh seperti itu? Don't..., we often like to, haphazardly convey something; say... what your campaign spokeman did. She said that she got those bruises on her face because of being punched, holding a pers conference together, what finally happened then? Plastic surgery... This nation is based on law supremacy. If there is a sufficient evidence, please follow law mechanism. Report it to the officers with some evidences. Very easy, very easy... this is a country of law supremacy. Why should (you) made such an allegation? (C.1.2)

The two data above contain argumentum ad hominem by way of attacking the supporter of the opponent. In (C.1.1) Prabowo attacks Jokowi by mentioning that the officers have made an unfair and excessive law enforcement. If the Prabowo' supporters broke the law, they are immedeately under arrest. But it did vice versa, if Jokowi's supporters did. Hence, there is an unjust feeling in the society. Meanwhile, in C.1.2 Jokowi fight back by mentioning that Prabowo' supporter have made a hoax by claiming that her bruised face is due to crimininal's punches taking place in Husen Sastranegara Airport, Bandung. Prabowo quickly responded to that hoax together with his vice-president candidate, Sandiaga Uno accompanied by their success team, holding a pers conference. After police's investigation, it is a pure hoax. This case is now under law mechanism process.

\subsection{Functions of Argumentum ad Hominem in the Debate of Presidential Candidates}

\section{2.1 Judging or Criticizing the debate opponent}

Data (A.1.1) and (B.1.1) are the examples of using argumentum ad hominem functioning as judging the policy of the opponent. The inappropriate policy is intentionally mentioned in order that the opponent is busy defending himself so that he has no chance for rebutting the opponent's claims. In (A.1.1), Prabowo criticized Jokowi's policy of distributing the land certificates for free. According to Prabowo, such a policy will last for one or two years only because there will be no additional production of land. What will happen to the next generation if there is no more land due to such an unaccounted policy. Judging the oponent's opinion was also done by Jokowi on Prabowo's claim. In (B.1.1), “Tapi menurut ICW, ini menurut ICW, partai yang Bapak pimpin termasuk yang paling banyak mencalonkan mantan koruptor atau mantan napi korupsi. (But according to ICW, your party has legalized ex-corruptors to be the legislator candidates). Jokowi criticized Prabowo to be inconsistent with his vision and mission, in which Prabowo stated that the corruption must be eradicated through its roots. However, his party in fact gives an endorsement for the excorruptors to become the coming legislators in a biggest number.

\subsubsection{Cornering the Opponent}


Datum (A.1.1) shows that the debate series are commenced by Prabowo's criticism on Jokowi's distribution of land certificates up to thousands of hectares. According to Prabowo, such a policy as the land cocession is of popular policy which lasts for only one or two generation(s) to come since there will be no land growth. He insisted a question on how the destiny of the coming children in future if such a land distribution goes on. For Prabowo, the strategy of protecting the natural resourcesshould be in accordance with UUD 45, verse 33, namely the earth and water and all resources within it must be under nation's authority and controll and be utilized as much as possible for people's welfare.

In response to such a criticism, Jokowi convey his argument (A.1.1), by which he attacked Prabowo who owns such a great deal of land, which is paradox with the effort of common people who hardly own land for farming. In fact, he is the presidential candidate who owns thousands of hectares of land in Kalimantan and Aceh. The sentence he used is of declarative form, i.e. "Saya tahu Pak Prabowo memiliki lahan yang sangat luas di Kalimantan Timur se sebesar 220 ribu hektar, juga di Aceh Tengah 120 ribu hektar. (I know that Mr. Prabowo has owned very large land in Kalimantan, as vast as $\mathbf{2 2 0 . 0 0 0}$ hectares, and 120.000 hectares in central Aceh as well)." However, its function is cornering the debate opponent, that is Prabowo.

For saving his face, Prabowo, in the end of debate, stated that the land under his legal concession is not a personal belonging but it is a mere Cultivation Rights 'Hak Guna Usaha" $(H G U)$. In fact, those lands belong to the country and he would readily return it if the country ask him to do so. In giving rebuttal to Jokowi's claim, Prabowo said that, “... tentang ee tanah yang katanya saya kuasai ratusan ribu (hektar) di beberapa tempat itu benar, tapi itu adalah $H G U$, itu adalah milik Negara. Jadi, setiap saat setiap negara bisa ambil kembali" (about the land of thousands hectares, that you said they are under my concession, that's true, but it is of $H G U$, it belongs to the country. Thus, whenever it is necessary, the state may take it back'

About the land under the concession, in the end of the debate Prabowo clarified that the land status is of $H G U$, not his own property. The supporters, especially Prabowo's national campaign team explains that those lands were acquired from foreign company which underwent non-performing loan, which was then bought by Prabowo. Thus, in this case, Prabowo is not the tycoon who owns thousands of hectares of land as alleged by most people. In fact, he just took over the land from the concession of a foreigner. If that is the case, Prabowo should have been appreciated as the true patriot taking over the land from the foreign corporation.

In interactional discourse, face-to-face as in a political debate, argument is constructed in such a way as to achieve the purpose of political debate. It is also true in political debates that show similar patterns. Moderator creates an emotional atmosphere by asking questions that is provocative and satirical. In the same cases, fallacies of argument are used in additon to the rational ones. In other words, political debate is a double game between presenting rational argument and avoiding it at the same time.

The interesting evidence found in political debates is the given questions that tend to purposfully attack the debate opponent. So does the argumentum ad hominem. It is frequently used to ask and answer a question in the political debates, either directly or indirectly. In traditional logic, such an argument belongs to the error of reasoning or fallacy. Even so, such a question can be used as an attacking strategy which has a strong effect [10]; [11].

Therefore, to understand argument in the political debate, Vedung offers two models of analysis, namely content analysis (content-oriented analysis) and function analysis (functionoriented analysis). The latter focuses on the context of a political message, by which the debater explains why a political message is delivered. When the question "Why is the 
statement delivered?", it is aimed not only seeking answers for justification but also generating motivation that drives a politician delivering the statement. Motivation is related to intention, calculation, and the purpose of a politician when delivering a political statement.

Referring to the relation between language and power, Bourdieu develops a forceful critique of traditional approach to language, including the linguistic theories of Saussure and Chomsky as well as the theory of speech-acts elaborated by Austin and others. He argues that language should be viewed not only as a means of communication but also as a medium of power through which individuals pursue their own interests and display their practical competence. Bourdieu maintains that linguistic utterances or expressions can be understood as the product of the relation between a "linguistic market" and "linguistic habitus." When individuals use language in a particular way, they deploy their accumulated linguistic resources and implicitly adapt their words to the demands of the social market, that is their audience. Hence every linguistic interaction, no matter personal or insignificant it may seem, hears the traces of the social structure that it both expresses and helps to reproduce. Bourdieu's account sheds fresh light on the ways in which linguistic usage varies according to considerations such as class and gender. It also opens up a new approach to the ways in which language is used in the domain of politics. For politics is, among other things, the arena in which words are deeds and the symbolic character of power is at stake [12].

Argumentum ad hominem is generally categorized as fallacies since there is no any irrelevant fact about the author or the person presenting the claim or argument. However, ad hominem reasoning is not always fallacious, for example, when it relates to the credibility of statements of fact [13]; [14]. Viewed from its relevant side, ad hominem is categorized into three, i.e.: (1) the abusive direct personal attack, (2) the circumstantial indirect personal attack, and (3) the you too! (tu quoque) variant. These fallacies were incorporated in items of three types: (1) a scientific discussion, (2) a political debate, and (3) a domestic discussion. They considered the direct personal attack least reasonable, then the indirect personal attack, then the tu quoque fallacy [15]; [16].

In political debate, ad hominem was once used by Northern newspapers to attack U.S. President, Abraham Lincoln's policies by attacking his character, using the terms drunk, baboon, too slow, foolish, and dishonest. Since then, argumentum ad hominem" has been carefully refined as an instrument of "oppo tactics" and "going negative" by the public relations experts who now craft political campaigns at the national level. It has been so prominently used in the major political campaigns, debates, and advertisements of the past few years. So far, there is no objection for the use of such an argument in th epolitical campaign [17]; [10]. Some ad hominem arguments are not only good arguments, but powerful ones as well. This thesis had an indirect effect among informal logicians and argumentation theorists. It helps to realize that not all ad hominem arguments, or all kinds of arguments associated with fallacy labels, are fallacious [18] [19].

\section{CONCLUSIONS}

Parallel to the study results and discussion previously presented by the researchers, some conclusions are drawn as: In Formal logic, argumentum ad hominem is categorized as a reasoning fallacy, yet in the political debate ad hominem reasoning is not always considered fallacious. In political debate, language should not merely percieved as a means of conveying a message but also a means of giving motivation and political calculation. As a suggestion, this is still the beginning of the study; therefore, it is recommended for the next researcher to conduct similar studies to deepen the existing focus on this study or examine other aspects of 
pragmatics in political debates such as aspects of the argument, rhetoric, critical discourse analysis, and so on. Further research should be conducted with a variety of approaches and methods and integrate them so that it may give a new more comprehensive approach in assessing the argumentum ad hominem in political debates.

\section{REFFERENCES}

[1] E. Vedung, Political Reasoning. Sage Publications, 1982.

[2] E. W. B. Hess-Lüttich, "(Pseudo-)Argumentation in TV-debates," J. Pragmat., vol. 39, no. 8, pp. 1360-1370, 2007.

[3] M. Luginbühl, "Conversational violence in political TV debates: Forms and functions," J. Pragmat., 2007.

[4] M. P. Geiser, "John Randolph of Roanoke and the Argumentum Ad Hominem ," Argumentation and Advocacy, vol. 36, no. 4, pp. 210-217, 2017.

[5] E. M. Barth and J. L. Martens, "Argumentum Ad Hominem: from Chaos to Formal Dialectic," Log. Anal., 1977.

[6] G. Lauerbach, "Argumentation in political talk show interviews," J. Pragmat., 2007.

[7] M. Jazeri, "PENALARAN ASOSIATIF DAN DISOSIATIF DALAM DEBAT POLITIK DI TELEVISI," Litera, vol. 11, no. 1, pp. 136-146, 2009.

[8] M. Jazeri, "Communication Culture in Political Debate in Indonesia," 2017, p. 364.

[9] Miles \& Huberman, Qualitative data analysis: An expanded sourcebook (3rd ed.). 2014.

[10] D. N. Walton, "Case Study of the Use of a Circumstantial Ad Hominem in Political Argumentation," Philos. Rhetor., 2007.

[11] H. Battaly, "Attacking character: Ad hominem argument and virtue epistemology," Informal Log., vol. 30, no. 4, pp. 361-390, 2010.

[12] I. Buchanan, P. Bourdieu, G. Raymond, and M. Adamson, "Language and Symbolic Power," SubStance, 2007.

[13] P. Rosen, "Ad hominem," Journal of Emergency Medicine, 2013.

[14] D. N. Walton, "The ad Hominem argument as an informal fallacy," Argumentation, vol. 1, no. 3, pp. 317-331, 1987.

[15] F. H. Van Eemeren, B. Meuffels, and M. Verburg, "The (un)reasonableness of ad hominem fallacies," J. Lang. Soc. Psychol., 2000.

[16] V. Bahna, "Argumentum ad hominem. Argumentation strategies of conspiracy theories advocates in slovak internet discussions," Narodop. Rev., 2017.

[17] F. H. Van Eemeren and R. Grootendorst, "The history of the Argumentum Ad Hominem since the seventeenth century," in Reasonableness and Effectiveness in Argumentative Discourse: Fifty Contributions to the Development of Pragma-Dialectics, 2015, pp. 611629.

[18] D. Hitchcock, "Is There an Argumentum ad Hominem Fallacy?," 2017, pp. 409-419.

[19] K. Saddhono, N. E. Wardani, and C. Ulya. "Sociopragmatic approach on discourse structure of friday prayer's sermon in java and madura island." J. of Lang and Lit, vol. 6 no. 1 pp 26-29, 2015. 